\title{
Article \\ Influence of Sandblasting and Chemical Etching on Titanium 99.2-Dental Porcelain Bond Strength
}

\author{
Malgorzata Lubas ${ }^{1, *(\mathbb{D}}$, Jaroslaw Jan Jasinski ${ }^{2}{ }^{\mathbb{D}}$, Anna Zawada ${ }^{1} \mathbb{D}$ and Iwona Przerada ${ }^{1}$ \\ 1 Department of Materials Engineering, Czestochowa University of Technology, Armii Krajowej 19, \\ 42-200 Czestochowa, Poland; anna.zawada@pcz.pl (A.Z.); iwona.przerada@pcz.pl (I.P.) \\ 2 National Centre for Nuclear Research, Materials Research Laboratory, 05-400 Otwock, Poland; \\ jaroslaw.jasinski@ncbj.gov.pl \\ * Correspondence: malgorzata.lubas@pcz.pl; Tel.: +48-343250764
}

Citation: Lubas, M.; Jasinski, J.J.; Zawada, A.; Przerada, I. Influence of Sandblasting and Chemical Etching on Titanium 99.2-Dental Porcelain Bond Strength. Materials 2022, 15, 116 https://doi.org/10.3390/ma15010116

Academic Editor: Gabriel Furtos

Received: 29 October 2021

Accepted: 22 December 2021

Published: 24 December 2021

Publisher's Note: MDPI stays neutral with regard to jurisdictional claims in published maps and institutional affiliations.

Copyright: (C) 2021 by the authors. Licensee MDPI, Basel, Switzerland. This article is an open access article distributed under the terms and conditions of the Creative Commons Attribution (CC BY) license (https:// creativecommons.org/licenses/by/ $4.0 /)$.

\begin{abstract}
The metal-ceramic interface requires proper surface preparation of both metal and ceramic substrates. This process is complicated by the differences in chemical bonds and physicochemical properties that characterise the two materials. However, adequate bond strength at the interface and phase composition of the titanium-bioceramics system is essential for the durability of dental implants and improving the substrates' functional properties. In this paper, the authors present the results of a study determining the effect of mechanical and chemical surface treatment (sandblasting and etching) on the strength and quality of the titanium-low-fusing dental porcelain bond. To evaluate the strength of the metal-ceramic interface, the authors performed mechanical tests (three-point bending) according to EN ISO 9693 standard, microscopic observations (SEM-EDS), and Raman spectroscopy studies. The results showed that depending on the chemical etching medium used, different bond strength values and failure mechanisms of the metal-ceramic system were observed. The analyzed samples met the requirements of EN ISO 9693 for metal-ceramic systems and received strength values above $25 \mathrm{MPa}$. Higher joint strength was obtained for the samples after sandblasting and chemical etching compared to the samples subjected only to sandblasting.
\end{abstract}

Keywords: titanium 99.2; metal-ceramic system; dental porcelain; bond strength; surface treatment

\section{Introduction}

Metal-ceramic joints are commonly used in dental restorations, mainly due to their adequate mechanical strength and aesthetics [1-3]. In dental prosthetics, many substrate materials are metal alloys, which highly affect the properties of the obtained metal-porcelain joint. Platinum, gold, silver-palladium, nickel-cobalt, and titanium alloys are mainly suitable [4-7]. However, non-precious alloys are characterized by low corrosion resistance, poor biocompatibility, insufficient bonding strength, or easily formed porcelain discolouration $[8,9]$.

The continuous development in biomaterials results in several studies evaluating tribological properties and the interactions between the human body and implants. In recent years, titanium and its alloys have enjoyed great success in dental applications. The continuous development in biomaterials results in several studies evaluating the interactions between the human body and titanium implants. Its main advantages include excellent biocompatibility, high strength, and corrosion resistance [10-13]. Unfortunately, such material is not without drawbacks. These include the cost of manufacturing and the complicated processing in prosthetic laboratories. Moreover, the detent to rapid surface oxidation causes some scientific papers to cite this as a primary reason for the weakening of the metal-ceramic system [14,15]. Many works have also been done on the titanium surface treatment, to obtain an accurate bonding strength of the metal-low-fusing porcelain system. Some of them concern thermal treatment, oxidation [16-18], modification by chemical etching [19-23], and laser treatment [24-27]. 
The most popular treatment of titanium surfaces used in prosthetic laboratories is sandblasting (abrasive treatment). Literature data show that the size of particles used during sandblasting is of great importance [24,28,29]. In the research performed by Walczak et al., different grain sizes of $\mathrm{Al}_{2} \mathrm{O}_{3}$ sand was used for the surface treatment [30]. It was shown that sandblasting particles with a diameter of $250 \mu \mathrm{m}$ provide a higher bond strength than particles of $50 \mu \mathrm{m}$. Smaller diameter particles can penetrate into the metal surface (up to 30\%), contaminating the substrate and weakening the bond between metal and dental porcelain. On the other hand, $\mathrm{Al}_{2} \mathrm{O}_{3}$ grains with a diameter of $250 \mu \mathrm{m}$ used for sandblasting may cause an increase in surface roughness, which result in an uneven distribution of the ceramic mass on the metal substrate. As a consequence, blisters form during firing and the porcelain may chip and crack during use [31]. Based on these reports, the most favorable grain size of $\mathrm{Al}_{2} \mathrm{O}_{3}$ medium for sandblasting metallic surfaces is above $50 \mu \mathrm{m}$ (optimum size 110-150 $\mu \mathrm{m})$ [32].

Other surface treatments widely known in the prosthetics industry are chemical bathing in aqueous solutions (sodium hydroxide) and acid etching. Several studies have been carried out to improve the bonding strength of titanium-ceramic systems using procedures involving chemical modification of the surface before porcelain application $[22,33]$. Many authors of works dealing with this field encourage dental practices to use this type of chemical surface treatment before firing ceramics due to the better quality of the titaniumporcelain bond and, above all, the availability and simplicity of the methods [18,34,35]. However, it should be remembered that many factors influence the titanium-porcelain bond (type of porcelain, processing parameters of the metal substrate, firing conditions of the porcelain layers), which makes research on the quality of the titanium-porcelain dental bond of continued interest [36-41].

In this paper, the authors present the results of a study on the influence of mechanochemical surface treatment on the quality and strength of a low-fusing titanium-dental porcelain joint. It is hypothesised that there is a strong relationship between surface modification methods and the strength of the metal-ceramic joint. Moreover, substrate chemical etching before firing the porcelain layer can increase the bond strength of the titanium-porcelain interface. To confirm this, the authors carried out various titanium surface treatments, combining sandblasting with chemical etching in different solutions.

\section{Materials and Methods}

\subsection{Samples Preparation}

The commercially pure titanium 99.2 (KOBE Steel Group Ltd.-KS60, ASTM B265 Grade 2, Tokyo, Japan) plates were used as the substrate material. Chemical composition of the material is presented in Table 1. Plates with the dimensions of $25( \pm 1) \mathrm{mm} \times 3( \pm 1) \mathrm{mm}$ $\times 0.5( \pm 1) \mathrm{mm}$ were cut using water jet technique (KIMLA Waterjet StreamCut 3030, Czestochowa, Poland) and prepared according to standard EN-ISO 9693-Metal ceramic dental systems [42].

Table 1. Chemical composition of technically pure titanium 99.2 according to ASTM 8348.

\begin{tabular}{cccccc}
\hline \multicolumn{7}{c}{ Element, [\% Mass] } \\
\hline $\mathrm{O}$ & $\mathrm{N}$ & $\mathrm{C}$ & $\mathrm{H}$ & $\mathrm{Fe}$ & $\mathrm{Ti}$ \\
0.25 & 0.03 & 0.08 & 0.015 & 0.30 & Balance \\
\hline
\end{tabular}

The samples were divided into three sets: Set 1 - samples sandblasted with $\mathrm{Al}_{2} \mathrm{O}_{3}-110 \mu \mathrm{m}$ (reference samples), Set 2-samples sandblasted with $\mathrm{Al}_{2} \mathrm{O}_{3}-110 \mu \mathrm{m}$ and chemically etched with $\mathrm{H}_{3} \mathrm{PO}_{4}$ or $\mathrm{HCl}$ acids, Set 3-samples sandblasted with $\mathrm{Al}_{2} \mathrm{O}_{3}-110 \mu \mathrm{m}$ and chemically treated in $50 \% \mathrm{NaOH}+10 \% \mathrm{CuSO}_{4}+5 \mathrm{H}_{2} \mathrm{O}$ solution in combination with etching in the $\mathrm{H}_{3} \mathrm{PO}_{4}$ or $\mathrm{HCl}$ acids. Abrasive surface treatment was performed using a sandblasting device (SANDBLAST RL7-FV, Prodento-Optimed, Warsaw, Poland) at pressure of 0.25-0.30 MPa, time $10 \mathrm{~s}$, sample position angle $\sim 50^{\circ}$ and nozzle-sample distance $-10 \mathrm{~mm}$. 
After the sandblasting and etching treatment, the samples were cleaned in distilled water using an ultrasonic cleaner for $5 \mathrm{~min}$. Detailed parameters of the sandblasting and surface etching of titanium 99.2 are summarized in Table 2.

Table 2. Variants of mechanical and chemical surface treatment of titanium 99.2 substrates.

\begin{tabular}{|c|c|c|}
\hline Lp. & Surface Treatment Type & Surface Treatment Parameters \\
\hline & & Sample Set 1 \\
\hline \multirow{3}{*}{1.} & \multirow{3}{*}{$\mathrm{Al}_{2} \mathrm{O}_{3}$ reference sample } & 1. Ultrasonic cleaning (room temp.) $-5 \mathrm{~min}$ \\
\hline & & 2. Sandblasting $\mathrm{Al}_{2} \mathrm{O}_{3}-1 \min ( \pm 5 \mathrm{~s})$ \\
\hline & & 3.Ultrasonic cleaning (room temp.) $-5 \mathrm{~min}$ \\
\hline \multirow{6}{*}{2.} & \multirow{6}{*}{$\mathrm{Al}_{2} \mathrm{O}_{3} / \mathrm{H}_{3} \mathrm{PO}_{4}$} & Sample Set 2 \\
\hline & & 1. Ultrasonic cleaning (room temp.) $-5 \mathrm{~min}$ \\
\hline & & 2. Sandblasting $\mathrm{Al}_{2} \mathrm{O}_{3}-1 \mathrm{~min}( \pm 5 \mathrm{~s})$ \\
\hline & & 3. Ultrasonic cleaning (room temp.) $-5 \mathrm{~min}$ \\
\hline & & 4. Etching $40 \% \mathrm{H}_{3} \mathrm{PO}_{4}-1 \mathrm{~min}$ \\
\hline & & 5. Ultrasonic cleaning (room temp.) $-5 \mathrm{~min}$ \\
\hline \multirow{5}{*}{3.} & \multirow{5}{*}{$\mathrm{Al}_{2} \mathrm{O}_{3} / \mathrm{HCl}$} & 1. Ultrasonic cleaning (room temp.) $-5 \mathrm{~min}$ \\
\hline & & 2. Sandblasting $\mathrm{Al}_{2} \mathrm{O}_{3}-1 \mathrm{~min}( \pm 5 \mathrm{~s})$ \\
\hline & & 3. Ultrasonic cleaning (room temp.) $-5 \mathrm{~min}$ \\
\hline & & 4. Etching $35 \% \mathrm{HCl}-1 \mathrm{~min}$ \\
\hline & & 5.Ultrasonic cleaning (room temp.) - $5 \mathrm{~min}$ \\
\hline \multirow{8}{*}{4.} & \multirow{8}{*}{$\begin{array}{c}\mathrm{Al}_{2} \mathrm{O}_{3} / \mathrm{NaOH}+10 \% \mathrm{CuSO}_{4} \\
+5 \mathrm{H}_{2} \mathrm{O} / \mathrm{H}_{3} \mathrm{PO}_{4}\end{array}$} & Sample Set 3 \\
\hline & & 1. Ultrasonic cleaning (room temp.) $-5 \mathrm{~min}$ \\
\hline & & 2. Sandblasting $\mathrm{Al}_{2} \mathrm{O}_{3}-1 \min ( \pm 5 \mathrm{~s})$ \\
\hline & & 3. Ultrasonic cleaning (room temp.) $-5 \mathrm{~min}$ \\
\hline & & 4. Etching in $50 \% \mathrm{NaOH}+10 \% \mathrm{CuSO}_{4}+5 \mathrm{H}_{2} \mathrm{O}-10 \mathrm{~min}$ \\
\hline & & 5. Ultrasonic cleaning (room temp.) $-5 \mathrm{~min}$ \\
\hline & & 6. Etching in $40 \% \mathrm{H}_{3} \mathrm{PO}_{4}$ acid- $-1 \mathrm{~min}$ \\
\hline & & 7. Ultrasonic cleaning (room temp.) $-5 \mathrm{~min}$ \\
\hline \multirow{7}{*}{5.} & \multirow{7}{*}{$\begin{array}{c}\mathrm{Al}_{2} \mathrm{O}_{3} / \mathrm{NaOH}+10 \% \mathrm{CuSO}_{4} \\
+5 \mathrm{H}_{2} \mathrm{O} / \mathrm{HCl}\end{array}$} & 1. Ultrasonic cleaning (room temp.) $-5 \mathrm{~min}$ \\
\hline & & 2. Sandblasting $\mathrm{Al}_{2} \mathrm{O}_{3}-1 \mathrm{~min}( \pm 5 \mathrm{~s})$ \\
\hline & & 3. Ultrasonic cleaning (room temp.) $-5 \mathrm{~min}$ \\
\hline & & 4. Etching in $50 \% \mathrm{NaOH}+10 \% \mathrm{CuSO}_{4}+5 \mathrm{H}_{2} \mathrm{O}-10 \mathrm{~min}$ \\
\hline & & 5. Ultrasonic cleaning (room temp.) $-5 \mathrm{~min}$ \\
\hline & & 6. Etching in $35 \% \mathrm{HCl}-1 \mathrm{~min}$ \\
\hline & & 7. Ultrasonic cleaning (room temp.) $-5 \mathrm{~min}$ \\
\hline
\end{tabular}

After the substrates' surface treatment, successive layers of Duceratin Kiss (DeguDent $\mathrm{GmbH}, \mathrm{Hanau}$, Germany) porcelain were formed on the titanium samples. The thickness of the porcelain layers was approximately $1.1 \mathrm{~mm}$ (Bond, Opaker, Dentin). The samples were then fired according to the manufacturer's recommendations. Firing of the Duceratin Kiss porcelain layers was carried out in accordance with the manufacturer's instructions [43]. The view of the finished samples after heat treatment is shown in Figure 1. 


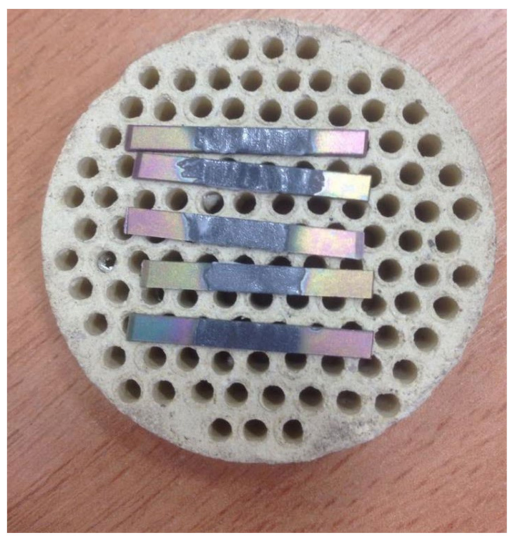

(a)

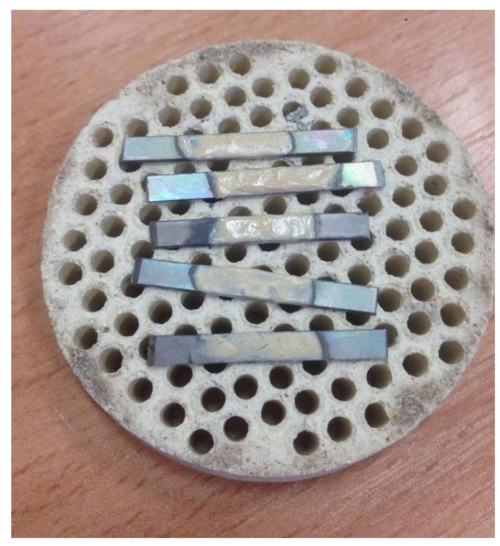

(b)

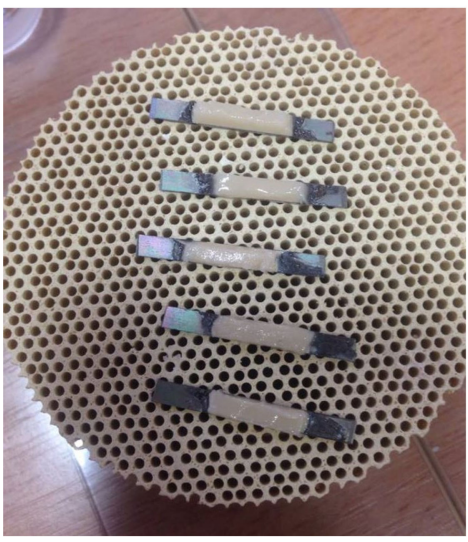

(c)

Figure 1. Titanium 99.2-Duceratin Kiss porcelain samples after firing process, (a) Bond, (b) Opaque, (c) Dentin.

\subsection{Microstructural Analysis and Mechanical Testing}

Microstructural observations were carried out together with chemical analysis in the micro areas of individual porcelain layers: Bond, Opaque, and Dentin. For the microstructural study, the scanning electron microscope (JEOL JSM-6610LV, Tokyo, Japan) equipped with an EDS analysis system was used. After the porcelain firing process, fracture force measurements were then performed, and the bond strength was determined for samples after different surface treatments. The three-point bending method was used for this purpose. Mechanical tests were carried out using a universal testing machine (Zwick/Roell GmbH \& Co. KG, Ulm, Germany) in accordance with EN ISO 9693 standard [42]. The test specimens were placed with the ceramic layer downwards, as shown in Figure 2.

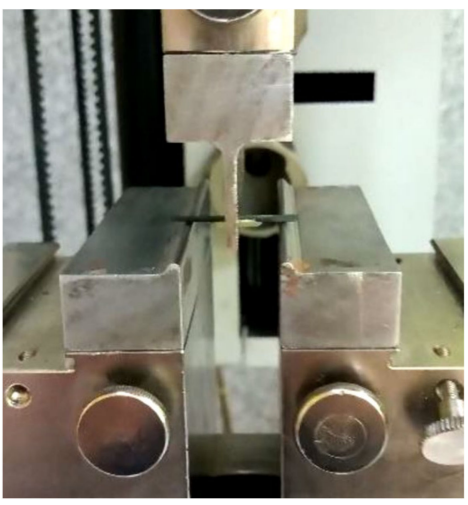

(a)

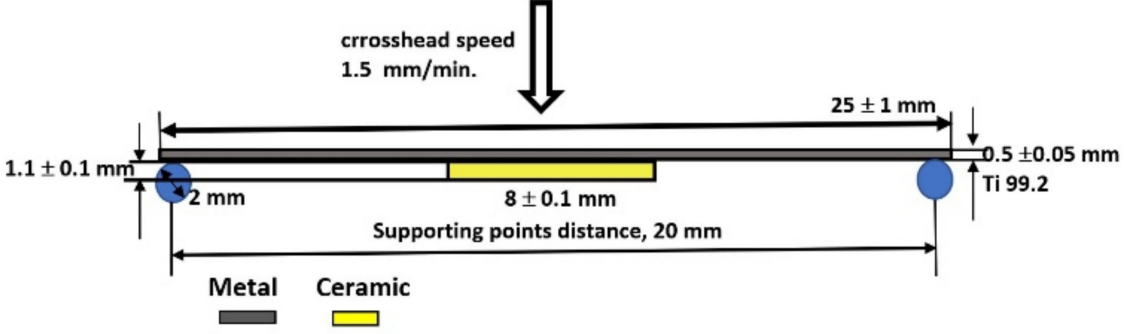

(b)

Figure 2. Mechanical testing of Duceratin Kiss porcelain samples (a) view of the samples arrangement in the bending system supports, (b) schematic view of the three-point bending test of a metal-ceramic system according to EN ISO 9693:2019 standard.

The measurement was carried out at a traverse feed rate of $1.5 \mathrm{~mm} / \mathrm{min}$ with a load of $0.6 \mathrm{~N}$. The breaking force $\mathrm{F}_{\text {fail }}$ was recorded as the maximum on the force-displacement curve.

The surface morphology and chemical composition of the samples after bending tests was also analyzed with a scanning electron microscopy (SEM-EDS) and Raman spectroscopy measurements using (Horiba Jobin Yvon LabRAM HR, Kioto, Japan) spectrometer equipped with Olympus BX-41 microscope (magnification 100×), Nd: YAG $532 \mathrm{~nm}$ green laser, with a power set to approx. $3 \mathrm{~mW}, 2$ scans with a total time of $120 \mathrm{~s}$ were accumulated. 
The obtained results finally allowed for the analysis of the surface modifications influence on the bond strength between titanium and dental porcelain.

\subsection{Bond Strenght Estimation and Statistical Analysis}

Then, using the $\mathrm{k}=\mathrm{f}\left(\mathrm{d}_{\mathrm{M}}\right)$ curve, where $\mathrm{d}_{\mathrm{M}}$ is the thickness of the metal plate, the $\mathrm{k}$ value was read and the adhesion of the porcelain to the titanium substrate was calculated according to EN ISO 9693 [42]. In determining the bond strength $\left(\tau_{\mathrm{b}}\right)$, the following formula was used:

$$
\tau_{\mathrm{b}}=\mathrm{k} \cdot \mathrm{F}_{\text {fail }}
$$

where:

$\mathrm{k}$ - coefficient depending on the thickness of the base metal and Young's modulus, $\mathrm{k}=4.6(\mathrm{E}=113 \mathrm{GPa},[41])$;

$\mathrm{F}_{\text {fail }}$-metal-ceramic bond breaking force

For all types of samples, five bending strength tests were realized, and then the mean value of the destructive force $\left(\mathrm{F}_{\max }\right)$ and bending strength $(\tau)$ were determined, as well as the standard deviation (SD) and the standard error of the mean value, that is, the standard deviation of the mean value distribution $\left(\mathrm{S}_{\mathrm{x}}\right)$. The obtained results were statistically analysed by ANOVA analysis of variance at a 0.05 significance level. The hypothesis about the significance of differences between the mean values of flexural strength of the analysed samples was verified (hypotheses $\mathrm{H}_{0}$ : all means are equal, $\mathrm{H}_{1}$ : not all means are equal). Furthermore after the ANOVA test, it was necessary to verify which of the compared samples are responsible for the rejection of $\mathrm{H}_{0}$ and to analyse which of the means differed from each other and which were equal. For this purpose, a more thorough examination of the differences between the means of the samples was realized by multiple comparisons post-hoc test. The Fisher LSD test was used in this study and the statistics were calculated as follows:

Hypotheses:

$\mathbf{H}_{0}: \mathrm{m}_{\mathrm{i}}=\mathrm{m}_{\mathrm{j}}$

$\mathrm{H}_{\mathbf{1}}: \mathrm{m}_{\mathrm{i}} \neq \mathrm{m}_{\mathrm{j}}$

where:

$i$ and $j$ represent each possible combination of pairs selected from $k$ averages

$$
\mathrm{s}_{\overline{\mathrm{x}}}=\mathrm{K} \cdot \mathrm{L} \cdot \sqrt{\mathrm{SK}}
$$

where:

$\mathrm{K}$-the factor that differentiates the value of the statistic for the test,

$\mathrm{L}$-number associated with the number of compared groups pairs

SK-intra-group variance calculated in the analysis of variance.

If $\left|\bar{x}_{\mathrm{i}}-\overline{\mathrm{x}}_{\mathrm{j}}\right| \geq \mathrm{s}_{\overline{\mathrm{x}}}$; then reject $\mathrm{H}_{0}$ and accept $\mathrm{H}_{1}$-means in compared populations differ significantly.

If $\left|\bar{x}_{i}-\bar{x}_{j}\right|<s_{\bar{x}}$; then there are no grounds to reject $\mathrm{H}_{0}$-means in compared populations do not differ significantly.

\section{Results and Discussion}

The correct metal-ceramic (dental porcelain) bond depends on many factors. Some of the most important include:

- $\quad$ surface roughness (by using blasting, unevenness is created on the metal surface, into which the porcelain penetrates, causing mechanical micro fixations) [32];

- compressive stresses caused by shrinkage of metal and porcelain (thermal expansion of porcelain should be slightly smaller than metal, in which case favorable compressive stresses will occur) [29]; 
- chemical bonding (during firing, metal oxides diffuse deep into the ceramic layers, combining with silicon oxides, and the bonds gradually change from metallic to ionic-covalent at the metal-ceramic interface) $[44,45]$.

In order to analyze the effect of surface treatment on the metal-ceramic bond, firstly tests were carried out on individual porcelain layers. This allowed to verify the chemical composition of the layers and analyze processes occurring during the firing of the metal-ceramic system. Microscopic studies of the individual porcelain layers are shown in Figure 3a-c.
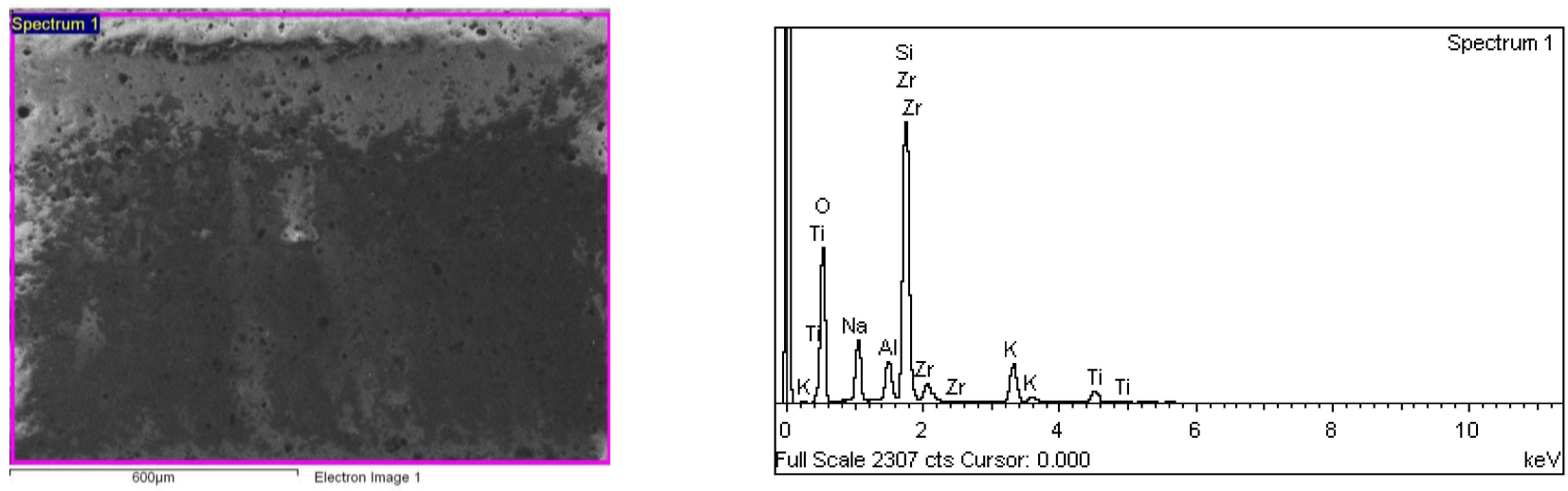

(a)
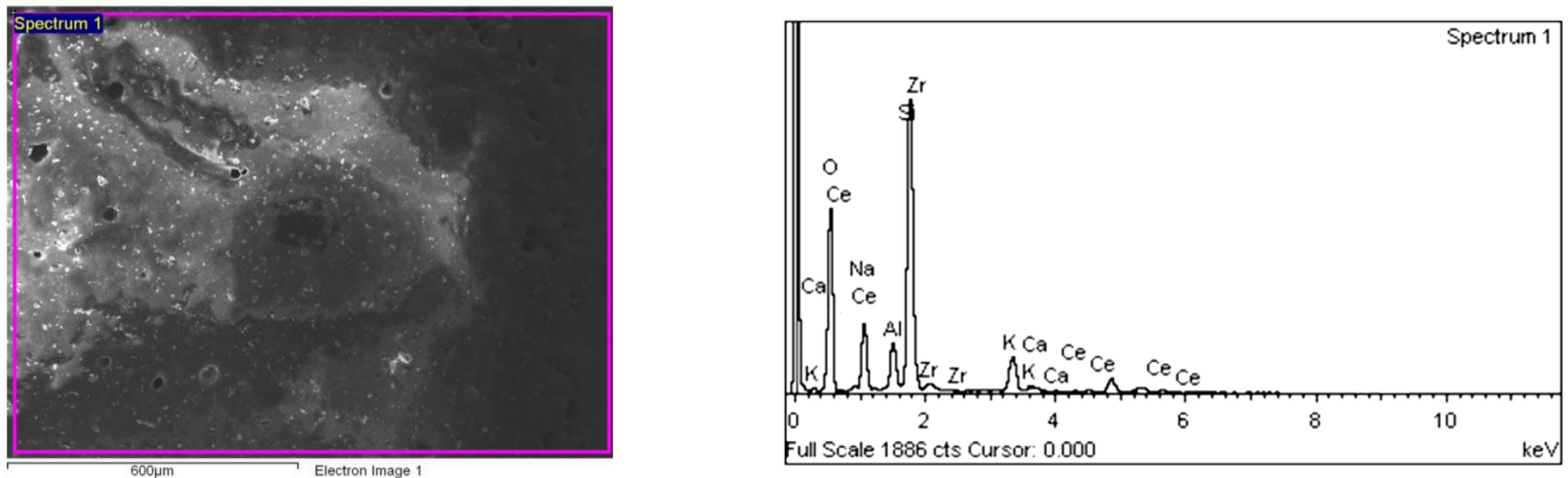

(b)
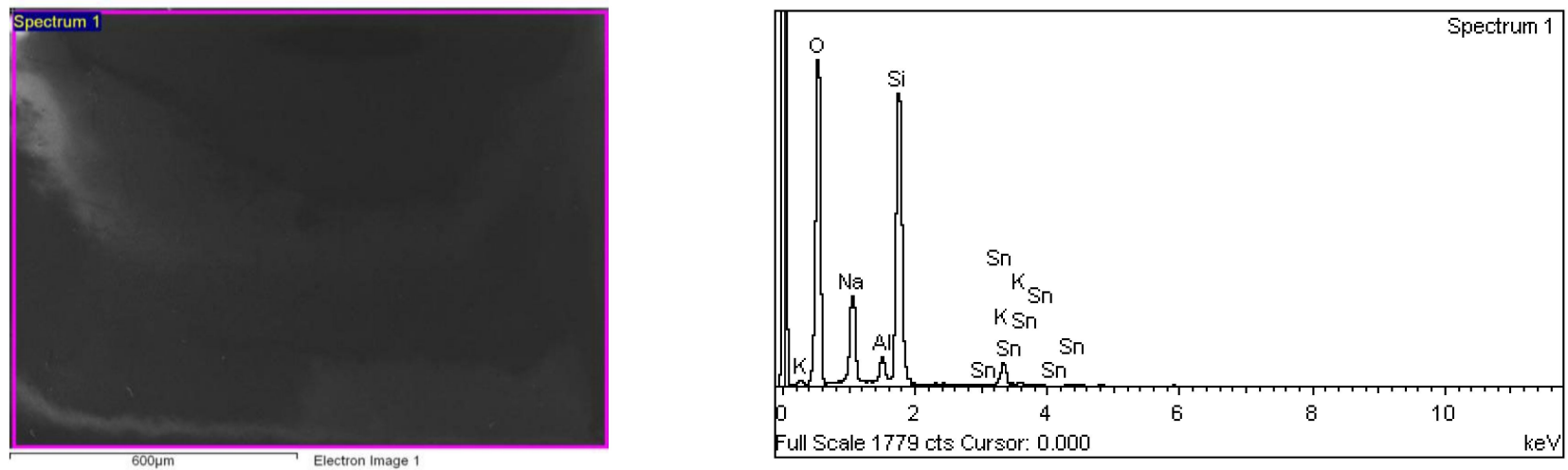

(c)

Figure 3. Microstructure and chemical analysis (SEM-EDS) of the substrates sandblasted with $\mathrm{Al}_{2} \mathrm{O}_{3}$ (reference sample) and coated with a Duceratin porcelain layers (a) Bond, (b) Opaque, (c) Dentin. 
Realized SEM-EDS analysis showed a slight difference in the individual layers of dental porcelain. The primary components of all porcelain layers are $\mathrm{Si}, \mathrm{Zr}, \mathrm{Al}, \mathrm{Na}, \mathrm{K}, \mathrm{Ca}$, $\mathrm{Ce}, \mathrm{Ti}$, and $\mathrm{O}$ (oxides mainly represent the porcelain composition). Moreover, each layer showed the presence of a different component. In the case of Bond, it was Zr; in Opaque, Ce was additionally revealed, and in the layer of Dentin, Sn was observed. All of these components highly influence the properties of dental porcelain. Zirconium oxide is mainly used as an opacifier, but it also affects the color change and increases the fatigue resistance of the porcelain [46]. Tin oxide is introduced to lower the melting point and increase the layer hardness, while the cerium oxide increases the strength of the metal-porcelain interface by forming complex compounds such as titanites [47]. Porcelain is joined with titanium at a temperature below $800{ }^{\circ} \mathrm{C}$. This range is suitable to prevent the formation of excessively thick oxide layers and optimal for the occurrence of a permanent and chemically stable metal-ceramic interface. The fracture force measurements and bond strength of titaniumdental porcelain systems and calculated elements necessary to determine the F test statistic are presented in Tables 3 and 4.

Table 3. Results of mechanical tests (three-point bending) for all variants of Ti 99.2-Duceratin Kiss samples after chemical and mechanical surface treatment.

\begin{tabular}{|c|c|c|c|c|c|c|c|}
\hline $\begin{array}{l}\text { Surface Treatment } \\
\text { Method }\end{array}$ & $\begin{array}{l}\text { Fracture } \\
\text { Type }\end{array}$ & $\begin{array}{c}\mathrm{F}_{\max } \text { Fracture Force } \\
{[\mathrm{N}]}\end{array}$ & $\begin{array}{l}\text { Standard } \\
\text { Deviation } \\
\text { SD }\end{array}$ & $\begin{array}{l}\text { Standard Error of } \\
\text { the Mean Value } \\
S_{x}\end{array}$ & $\begin{array}{c}\tau \text {-Bending } \\
\text { Strength Mean Value } \\
{[\mathrm{MPa}]}\end{array}$ & $\begin{array}{l}\text { Standard } \\
\text { Deviation } \\
\text { SD }\end{array}$ & $\begin{array}{c}\text { Standard Error of } \\
\text { the Mean Value } \\
\qquad S_{x}\end{array}$ \\
\hline \multicolumn{8}{|c|}{ Sample Set 1} \\
\hline $\mathrm{Al}_{2} \mathrm{O}_{3}$ reference sample & Adhesive & 6.54 & 1.22 & 0.55 & 30.08 & 5.79 & 2.50 \\
\hline \multicolumn{8}{|c|}{ Sample Set 2} \\
\hline $\mathrm{Al}_{2} \mathrm{O}_{3} / \mathrm{H}_{3} \mathrm{PO}_{4}$ & Cohesive & 8.15 & 1.26 & 0.56 & 39.16 & 2.06 & 0.92 \\
\hline $\mathrm{Al}_{2} \mathrm{O}_{3} / \mathrm{HCl}$ & Cohesive & 9.17 & 1.11 & 0.50 & 42.17 & 5.10 & 0.28 \\
\hline \multicolumn{8}{|c|}{ Sample Set 3} \\
\hline $\begin{array}{c}\mathrm{Al}_{2} \mathrm{O}_{3} / \mathrm{NaOH}+\mathrm{CuSO}_{4} \\
+5 \mathrm{H}_{2} \mathrm{O} / \mathrm{H}_{3} \mathrm{PO}_{4}\end{array}$ & $\begin{array}{l}\text { Adhesive/ } \\
\text { Cohesive }\end{array}$ & 8.92 & 1.17 & 0.52 & 40.31 & 3.76 & 1.68 \\
\hline $\begin{array}{c}\mathrm{Al}_{2} \mathrm{O}_{3} / \mathrm{NaOH}+\mathrm{CuSO}_{4} \\
+5 \mathrm{H}_{2} \mathrm{O} / \mathrm{HCl}\end{array}$ & $\begin{array}{l}\text { Adhesive/ } \\
\text { Cohesive }\end{array}$ & 10.59 & 1.39 & 0.62 & 48.77 & 2.88 & 1.29 \\
\hline
\end{tabular}

Table 4. Values of the F test statistic by ANOVA analysis of variance.

\begin{tabular}{ccccc}
\hline Source of Variation & Sum of Squares of Deviations & Degrees of Freedom & Variance & Test F \\
\cline { 1 - 5 } Between groups & $\mathrm{a}=917.71$ & $\mathrm{~b}=4$ & $\frac{\mathrm{a}=229.43}{\mathrm{~b}}$ & $\mathrm{~F}=\frac{229.43}{17.38}=13.20$ \\
\hline Inside groups & $\mathrm{c}=347.59$ & $\mathrm{~d}=20$ & $\frac{\mathrm{c}}{\mathrm{d}}=17.38$ & \\
\hline
\end{tabular}

The presented statistics have the Fisher-Snedecor distribution with $(\mathrm{k}-1, n-\mathrm{k})$ degrees of freedom. F-statistic values greater than the critical values are the basis for the rejection of the null hypothesis (the hypothesis of equality of variance) in favor of an alternate hypothesis that indicates the presence of convergence or divergence. From the F distribution tables for the set significance level of 0.05 and for $\mathrm{k}-1=4$ and $n-\mathrm{k}=20$ degrees of freedom, the critical value $F_{\alpha}=2.87$ was read. Since $F>F_{\alpha}$, therefore, at the significance level of $0.05, \mathrm{H}_{0}$ was rejected in favor of $\mathrm{H}_{1}$, which means that the average values of flexural strength differ between sample sets. Moreover, since the null hypothesis has been rejected, it is therefore necessary to verify which of the compared samples are responsible for the rejection of $\mathrm{H}_{0}$. It was analysed which of the means differed from each other and which were equal. For this purpose, as mentioned, multiple comparisons Fisher LSD post-hoc test was carried out. The intra-group variance calculated in the analysis of variance was $\mathrm{SK}=17.38$ and $\mathrm{K}=2.086$. The results of the Fisher LSD test are presented in Table 5. 
Table 5. Comparison of samples for significance of differences in mean flexural strength measurements by post-hoc Fisher LSD test.

\begin{tabular}{ccccc}
\hline $\begin{array}{c}\text { Paired Samples } \\
\text { Combination * }\end{array}$ & $\begin{array}{r}\text { Differences between Means } \\
-\bar{x}_{i}-\bar{x}_{j} \mid\end{array}$ & L & $s_{x}^{-}$ & $\left|\bar{x}_{i}-\bar{x}_{j}\right| \geq s_{x}$ \\
\hline $1-2$ & 9.08 & 0.632 & 5.49 & + \\
\hline $1-3$ & 12.09 & 0.632 & 5.49 & + \\
\hline $1-4$ & 10.23 & 0.632 & 5.49 & + \\
\hline $1-5$ & 18.69 & 0.632 & 5.49 & + \\
\hline
\end{tabular}

" + " the means in the populations compared are significantly different. ${ }^{*}$ samples numbered according to Table 2.

According to EN ISO 9693 [42], dental porcelain fired on a metal substrate shall exhibit a minimum strength of $25 \mathrm{MPa}$ when tested in three-point bending. When analyzing the results, it was found that all samples after mechanical and chemical surface treatment fulfilled such requirement. When comparing the results, it was found that the weakest bond between titanium and porcelain was obtained for substrates subjected to single sandblasting (Sample Set 1-30.08 MPa). Intermediate values were obtained for samples etched in $\mathrm{H}_{3} \mathrm{PO}_{4}$ acid $\left(39.16 \mathrm{MPa}\right.$ ) and immersed in the caustic bath $\mathrm{NaOH}+\mathrm{CuSO}_{4}+5 \mathrm{H}_{2} \mathrm{O}$ and $\mathrm{H}_{3} \mathrm{PO}_{4}$ acid etched $(40.31 \mathrm{MPa})$. The highest values were observed for the substrates subjected to mechanochemical treatment both with etching in the $35 \% \mathrm{HCl}$ acid (Sample Set 2) and the caustic bath $\mathrm{NaOH}+\mathrm{CuSO}_{4}+5 \mathrm{H}_{2} \mathrm{O}$ and $\mathrm{HCl}$ acid (Sample Set 3). The joint strength values were $42.17 \mathrm{MPa}$ and $48.77 \mathrm{MPa}$, respectively. Therefore, it can be concluded that the surface etching techniques carried out for titanium substrates allowed better adhesion, and fully meet the requirements set by EN ISO 9693 standard [42]. The obtained bond strength results were higher than available literature data for similar mechanochemical surface treatments $[33,48]$. The authors in the research used Duceratin Kiss porcelain, which according to literature data, has higher flexural strength values than other low-fusing porcelains [49]. That is also the reason for assessing the strength of the metal-ceramic bond with regard to the type of porcelain, as its chemical composition and firing conditions may influence the value of the metal-ceramic interface strength.

After the three-point bending mechanical test, based on which the strength of the titanium-porcelain joint was determined, the surfaces (on the metal area) were subjected to morphological examination using a scanning electron microscopy. The microstructure and chemical composition analysis (SEM-EDS) results are shown in Figure 4a-e.

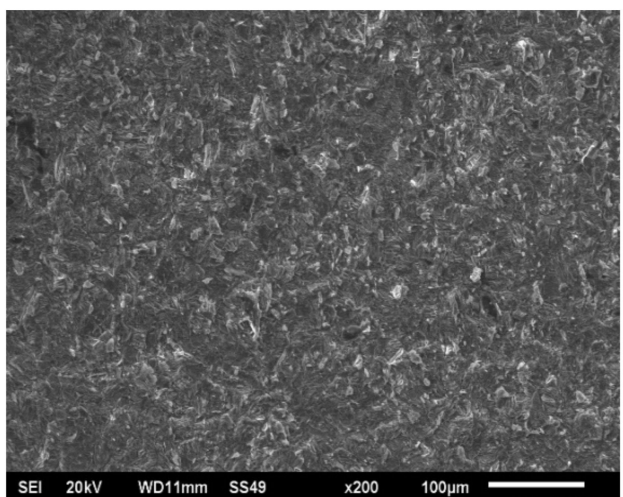

(a)

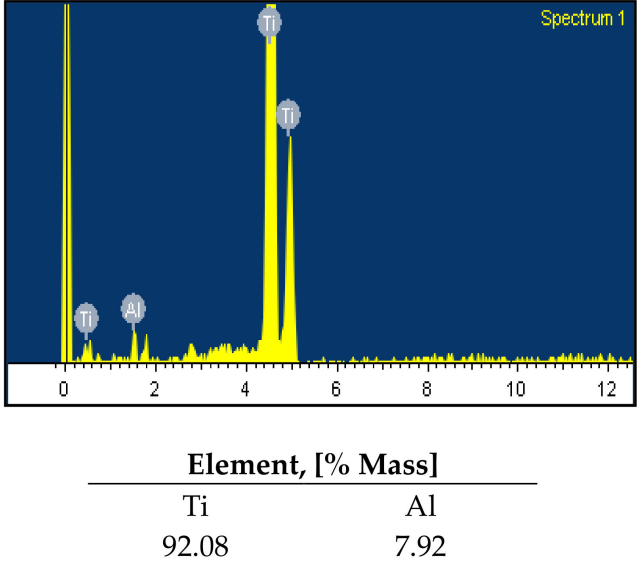

Figure 4. Cont. 

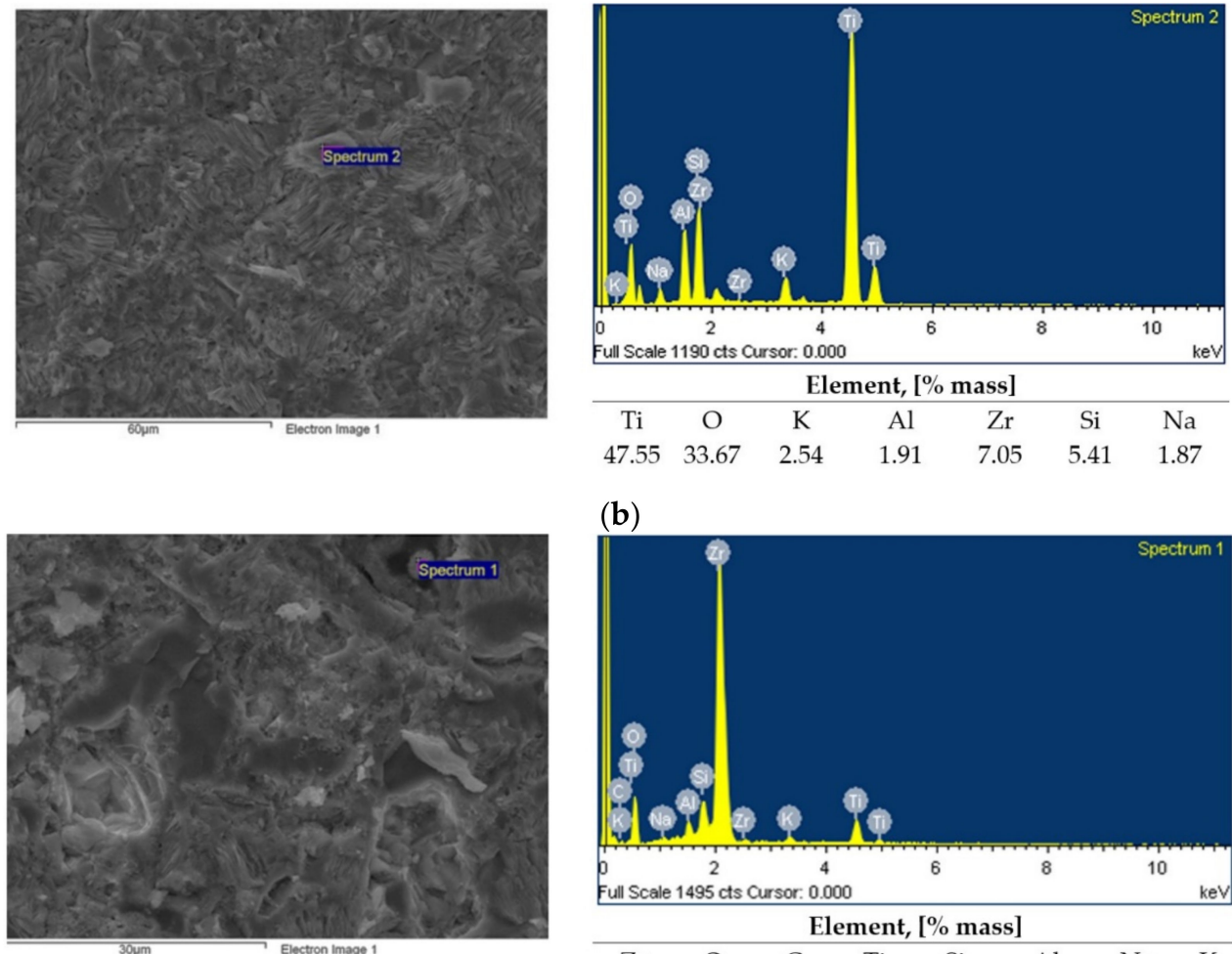

(b)

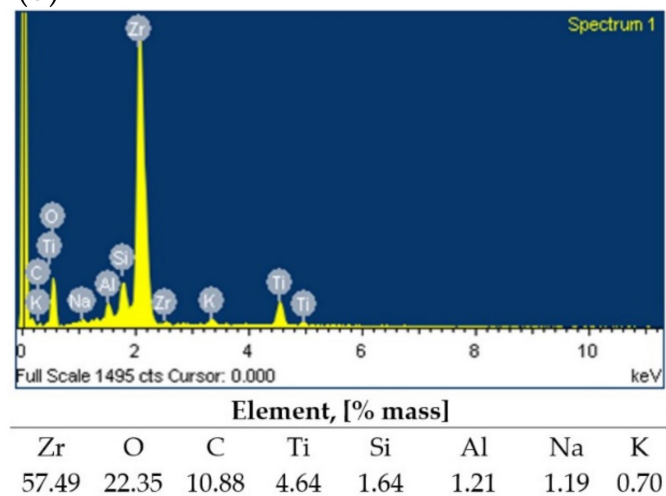

(c)
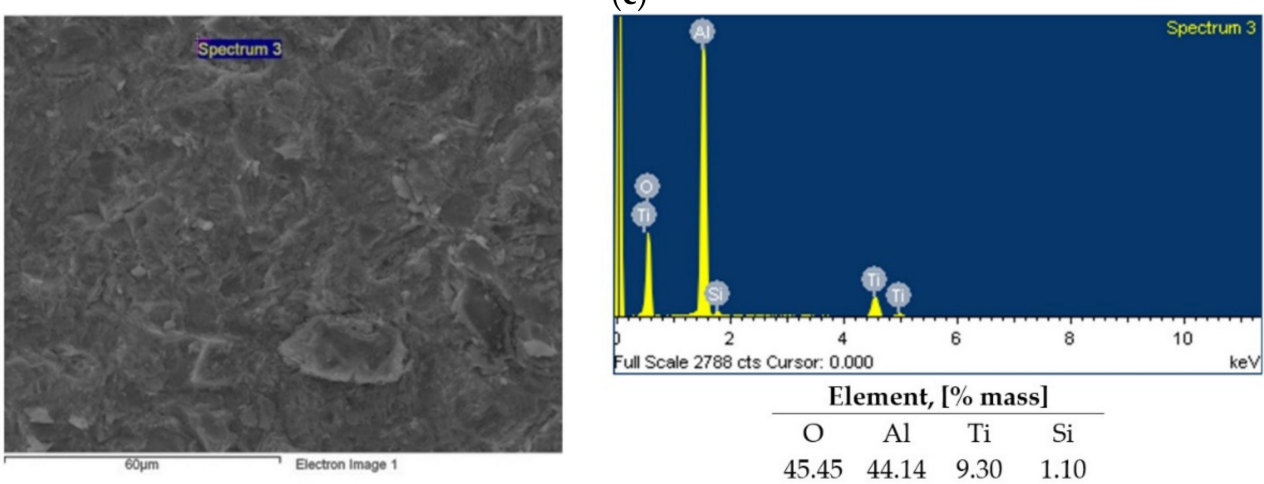

(d)
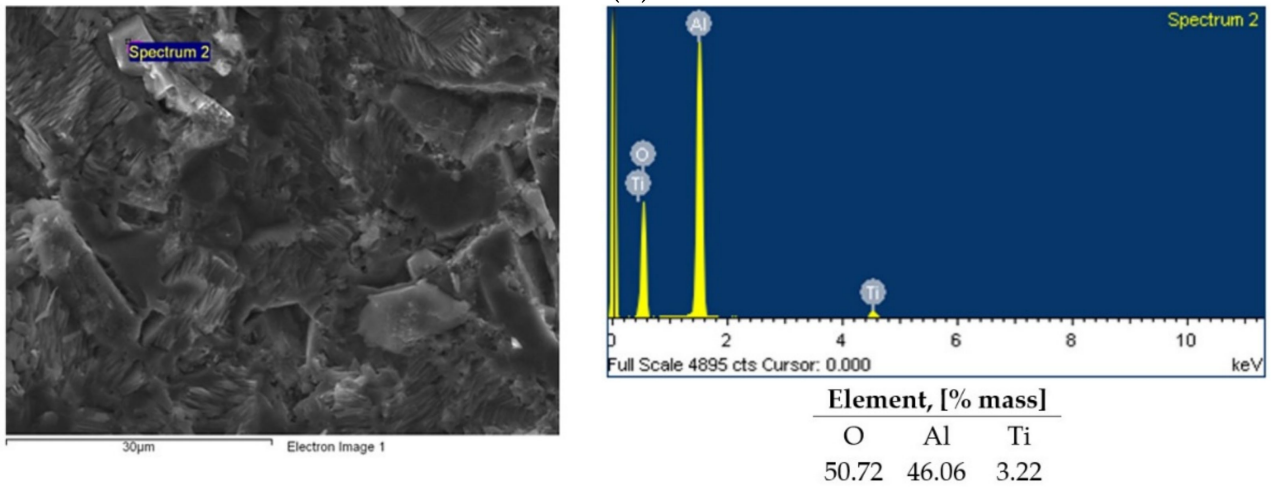

(e)

Figure 4. Microstructure and chemical composition analysis (SEM-EDS) of titanium 99.2-Duceratin Kiss samples after mechanochemical surface treatment, (a) sandblasted with $\mathrm{Al}_{2} \mathrm{O}_{3}$, (b) sandblasted with $\mathrm{Al}_{2} \mathrm{O}_{3}$ and $\mathrm{H}_{3} \mathrm{PO}_{4}$ acid etched, (c) sandblasted with $\mathrm{Al}_{2} \mathrm{O}_{3}$ and $\mathrm{HCl}$ acid etched, (d) sandblasted with $\mathrm{Al}_{2} \mathrm{O}_{3}$ and $10 \% \mathrm{NaOH}+\mathrm{CuSO}_{4}+5 \mathrm{H}_{2} \mathrm{O} / \mathrm{H}_{3} \mathrm{PO}_{4}$ solution etched, (e) sandblasted with $\mathrm{Al}_{2} \mathrm{O}_{3}$ and $10 \% \mathrm{NaOH}+\mathrm{CuSO}_{4}+5 \mathrm{H}_{2} \mathrm{O} / \mathrm{HCl}$ solution etched. 
When analysing the surfaces, different types of damage were observed at the titaniumporcelain interface. In case of the samples from set 1 (reference sample), a complete detachment of the porcelain layers from the titanium substrate occurred according to the adhesive mechanism (all samples). SEM-EDS analysis for the mentioned variant mainly showed $\mathrm{Ti}$ and $\mathrm{Al}$ presence (Figure $4 \mathrm{a}$ ). The presence of Al may suggest that during the sandblasting process, $\mathrm{Al}_{2} \mathrm{O}_{3}$ particles penetrate deep into the titanium surface. Consequently, this may affect the weakening of the titanium 99.2-Duceratin Kiss bond [50]. Analysis of the titanium surface for the sample set $2\left(\mathrm{Al}_{2} \mathrm{O}_{3} / \mathrm{H}_{3} \mathrm{PO}_{4}\right.$ and $\left.\mathrm{Al}_{2} \mathrm{O}_{3} / \mathrm{HCl}\right)$ showed the presence of porcelain components such as $\mathrm{Zr}, \mathrm{Si}, \mathrm{K}, \mathrm{Na}$ (Figure $4 \mathrm{~b}, \mathrm{c}$ ). It indicates that the bond fracture occurred in all of the samples at the level of the porcelain layer according to the cohesive mechanism (Figure $5 \mathrm{C})$. For the samples from set $3\left(\mathrm{Al}_{2} \mathrm{O}_{3} / 50 \% \mathrm{NaOH}\right.$ $+10 \% \mathrm{CuSO}_{4}+\mathrm{H}_{2} \mathrm{O} / \mathrm{H}_{3} \mathrm{PO}_{4}$ and $\mathrm{Al}_{2} \mathrm{O}_{3} / 50 \% \mathrm{NaOH}+10 \% \mathrm{CuSO}_{4}+5 \mathrm{H}_{2} \mathrm{O} / \mathrm{HCl}$ ), a mixed adhesive-cohesive type of fracture was observed and only one sample showed adhesive failure (Figure $4 \mathrm{~d}, \mathrm{e}$ ). Despite the lower bond strength values obtained for samples etched only in acids (Sample Set 2), these substrates had a cohesive type of fracture, which is favorable from a clinical application viewpoint and most desired in metal-ceramic systems used in dentistry [51-53].
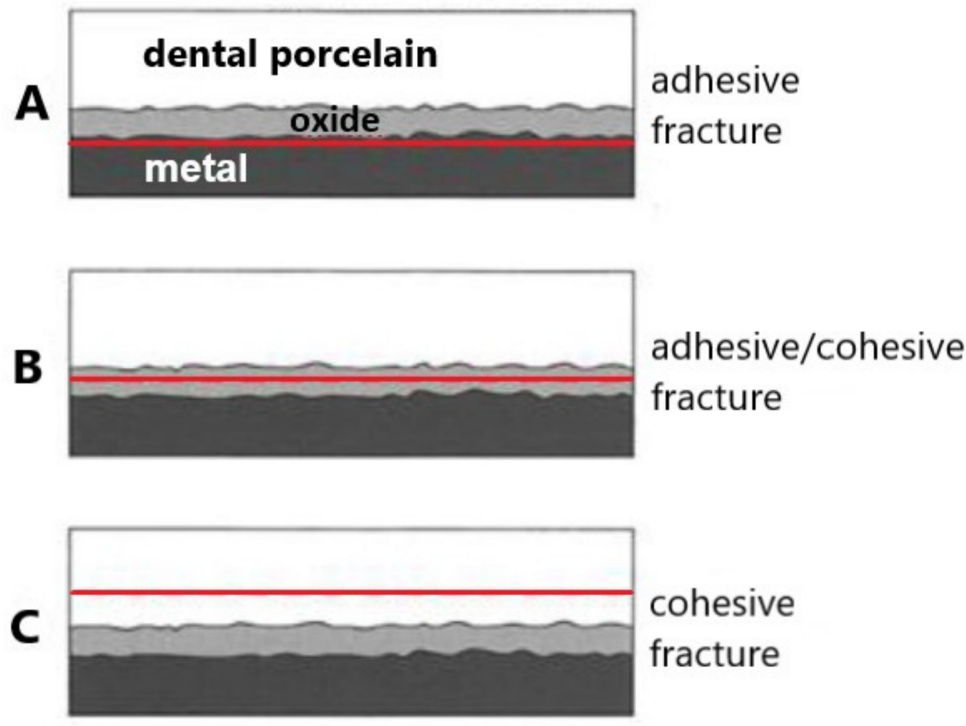

Figure 5. Fracture types of the Ti 99.2-Duceratin Kiss porcelain bond, (A) metal-oxide layer, (B) oxide layer-oxide layer, (C) porcelain layer-porcelain layer [53].

The differences between the titanium 99.2-porcelain interface were also investigated by Raman spectroscopy measurements (Figure 6). The chemical analysis realized for the metalceramics joint have shown that the samples sandblasted with $\mathrm{Al}_{2} \mathrm{O}_{3}$ (reference samples) showed the bands coming from the $\mathrm{TiO}_{2}$ rutile phase (at approx. 613 and $447 \mathrm{~cm}^{-1}$ ) (Figure $6 \mathrm{~b}$-band (e)) and the bands from the Ti 99.2-Duceratin Kiss porcelain interface chemical bonding $\left(940 \mathrm{~cm}^{-1}\right)$ (Figure 6a-band $\left.(\mathrm{a}, \mathrm{b}, \mathrm{c}, \mathrm{d})\right)$ [45]. The Raman spectra obtained for $\mathrm{TiO}_{2}$ rutile may indicate the effect of titanium substrates oxidation during the firing process of porcelain layers. The analysis of these issues is the subject of research currently carried out by the authors and the results will be presented in the following papers. Moreover, the Raman spectroscopy results showed phase distribution change along the interface, which proved the different character of metallic and ceramic chemical bonding, which changed slightly from metallic to ionic/covalent nature. 


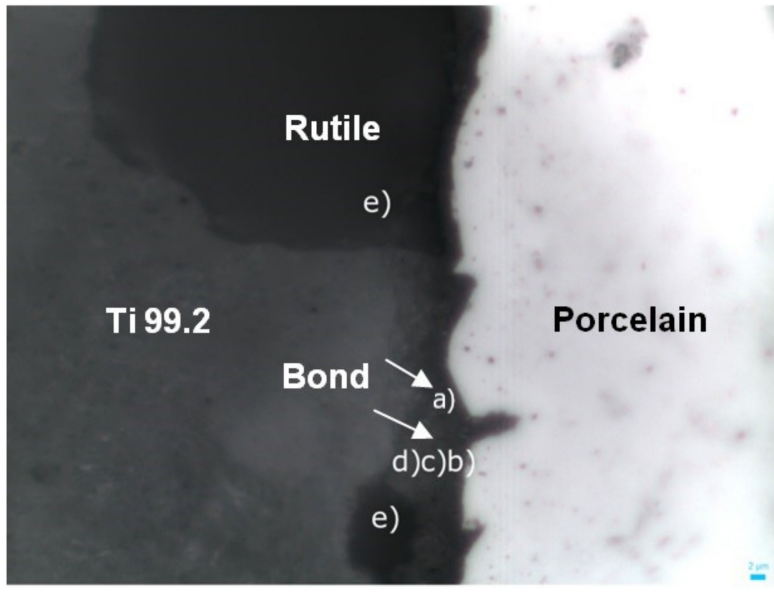

(a)

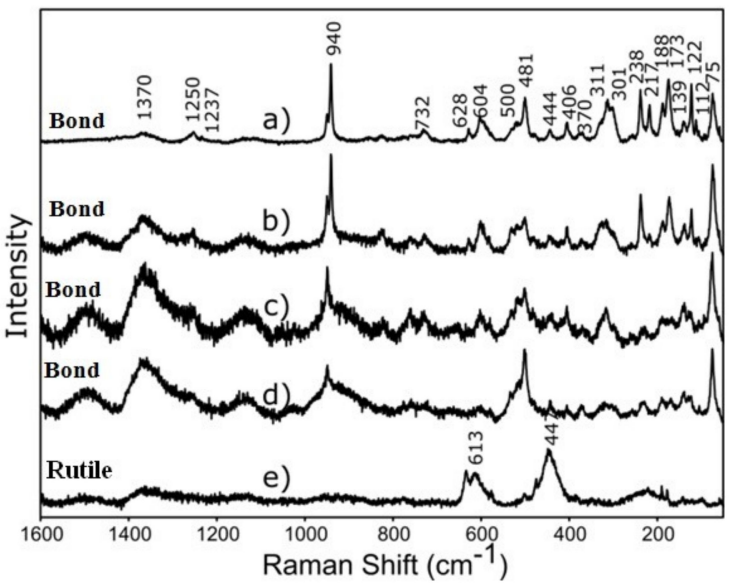

(b)

Figure 6. Raman spectroscopy measurements of titanium 99.2-Duceratin Kiss dental porcelain system (a) microscopic image of the metal-porcelain interface (b) Raman spectra of the bonding area.

\section{Conclusions}

The performed tests showed that chemical etching in $50 \% \mathrm{NaOH}+10 \% \mathrm{CuSO}_{4}+5 \mathrm{H}_{2} \mathrm{O}$ solution and $\mathrm{H}_{3} \mathrm{PO}_{4}$ or $\mathrm{HCl}$ acids improve titanium-porcelain bonding and porcelain adhesion to the titanium substrates. It should be emphasized that all of the samples met the requirements of EN ISO 9693:2019 standard [42], where the bond strength should be greater than $25 \mathrm{MPa}$. The highest bond strength value of the metal-ceramic system (48.77 $\mathrm{MPa})$ was obtained for samples sandblasted with $\mathrm{Al}_{2} \mathrm{O}_{3}$ and immersed in a caustic bath and $\mathrm{HCl}$ acid etched. Furthermore, different types of titanium 99.2-porcelain Duceratin Kiss bond fracture mechanisms were observed. For sample set 2, which was sandblasted and $\mathrm{H}_{3} \mathrm{PO}_{4}$ or $\mathrm{HCl}$ acid etched, the joint was found to a cohesive fracture in the region of the ceramic layers, which is the most desired type of titanium-porcelain system failure in dentistry. In conclusion, it should be stated that realized research provides a rationale for the effective use of mechanochemical treatment processes in prosthetic laboratories to achieve favorable metal-ceramic bonds and high-quality dental implants.

Author Contributions: Conceptualization, M.L., J.J.J. and A.Z.; methodology, M.L. and A.Z.; data analysis and validation, M.L., A.Z. and I.P.; performing research and investigation, M.L., A.Z. and I.P.; writing-original draft preparation, M.L., J.J.J. and A.Z.; supervision, M.L. and J.J.J.; funding acquisition, M.L. All authors have read and agreed to the published version of the manuscript.

Funding: This research received no external funding.

Institutional Review Board Statement: Not applicable.

Informed Consent Statement: Not applicable.

Data Availability Statement: The data presented in this study are available on request from the corresponding author. The data are not publicly available due to possibility for use in further re-search.

Conflicts of Interest: The authors declare no conflict of interest.

\section{References}

1. Ananth, H.; Kundapur, V.; Mohammed, H.S.; Anand, M.; Amarnath, G.S.; Mankar, S. A Review on Biomaterials in Dental Implantology. Int. J. Biomed. Sci. IJBS 2015, 11, 113-120.

2. Hey, J.; Beuer, F.; Bensel, T.; Boeckler, A.F. Metal-ceramic-fixed dental prosthesis with CAD/CAM-fabricated substructures: 6-year clinical results. Clin. Oral Investig. 2012, 17, 1447-1451. [CrossRef]

3. Hey, J.; Beuer, F.; Bensel, T.; Boeckler, A.F. Single crowns with CAD/CAM-fabricated copings from titanium: 6-year clinical results. J. Prosthet. Dent. 2014, 112, 150-154. [CrossRef] 
4. Zhou, Y.; Li, N.; Wang, H.; Yan, J.; Liu, W.; Xu, S. Effects of the rare earth element lanthanum on the metal-ceramic bond strength of dental casting Co-Cr alloys. J. Prosthet. Dent. 2019, 121, 848-857. [CrossRef] [PubMed]

5. Knosp, H.; Holliday, R.J.; Corti, C.W. Gold in dentistry: Alloys, uses and performance. Gold Bull. 2003, 36, 93-102. [CrossRef]

6. $\mathrm{Wu}, \mathrm{J} . ; \mathrm{Zhou}, \mathrm{J} . ; \mathrm{Zhao}, \mathrm{W}$; Gao, B. Evaluation of the bond strength of a low-fusing porcelain to cast Ti-24Nb-4Zr-7.9Sn alloy. Mater. Sci. Eng. C 2013, 33, 140-144. [CrossRef] [PubMed]

7. Takemoto, S.; Hattori, M.; Yoshinari, M.; Kawada, E.; Asami, K.; Oda, Y. Corrosion mechanism of Ti-Cr alloys in solution containing fluoride. Dent. Mater. 2009, 25, 467-472. [CrossRef]

8. Tamac, E.; Kumbuloglu, T.O.; Toksavul, S.; Toman, M.; Sarikanat, M. Effects of sandblasting and silicoating on bond strength between titanium and porcelain. Niger. J. Clin. Pract. 2018, 21, 1177-1181. [PubMed]

9. Dolgov, N.A.; Dikova, T.; Dzhendov, D.; Pavlova, D.; Simov, M. Mechanical properties of dental Co-Cr alloys fabricated via Casting and Selective Laser Melting. Mater. Sci. Nonequilib. Phase Transform 2016, 3, 3-7.

10. Tschernitschek, H.; Borchers, L.; Geurtsen, W. Nonalloyed titanium as a bioinert metal—A review. J. Prosthet. Dent. 2006, $96,12$. [CrossRef]

11. Novaes, A.B., Jr.; De Souza, S.L.S.; De Barros, R.R.M.; Pereira, K.K.Y.; Iezzi, G.; Piattelli, A. Influence of implant surfaces on osseointegration. Braz. Dent. J. 2010, 21, 471-481. [CrossRef] [PubMed]

12. Jivraj, S.; Chee, W. Rationale for dental implants. Br. Dent. J. 2006, 200, 661-665. [CrossRef] [PubMed]

13. Javed, F.; Romanos, G.E. The role of primary stability for successful immediate loading of dental implants. A literature review. J. Dent. 2010, 38, 612-620. [CrossRef]

14. Kimura, H.; Horng, C.-J.; Okazaki, M.; Takahashi, J. Oxidation Effects on Porcelain-Titanium Interface Reactions and Bond Strength. Dent. Mater. J. 1990, 9, 91-99. [CrossRef]

15. Papadopoulos, T.D.; Spyropoulos, K.D. The effect of a ceramic coating on the cpTi-porcelain bond strength. Dent. Mater. 2009, 25, 247-253. [CrossRef]

16. Kurup, A.; Dhatrak, P.; Khasnis, N. Surface modification techniques of titanium and titanium alloys for biomedical dental applications: A review. Mater. Today Proc. 2020, 39, 84-90. [CrossRef]

17. Wang, R.R.; Fung, K.K. Oxidation behavior of surface-modified titanium for titanium-ceramic restorations. J. Prosthet. Dent. 1997, 77, 423-434. [CrossRef]

18. Al Hussaini, I.; Al Wazzan, K.A. Effect of surface treatment on bond strength of low-fusing porcelain to commercially pure titanium. J. Prosthet. Dent. 2005, 94, 350-356. [CrossRef]

19. Ramakrishnaiah, R.; Alkheraif, A.A.; Divakar, D.D.; Matinlinna, J.P.; Vallittu, P.K. The Effect of Hydrofluoric Acid Etching Duration on the Surface Micromorphology, Roughness, and Wettability of Dental Ceramics. Int. J. Mol. Sci. 2016, 17, 822. [CrossRef]

20. Kim, J.-T.; Cho, S.-A. The effects of laser etching on shear bond strength at the titanium ceramic interface. J. Prosthet. Dent. 2009, 101, 101-106. [CrossRef]

21. Egoshi, T.; Taira, Y.; Soeno, K.; Sawase, T. Effects of sandblasting, $\mathrm{H}_{2} \mathrm{SO}_{4} / \mathrm{HCl}$ etching, and phosphate primer application on bond strength of veneering resin composite to commercially pure titanium grade 4. Dent. Mater. J. 2013, 32, 219-227. [CrossRef]

22. Gökçe, B.; Ozpinar, B.; Dündar, M.; Cömlekoglu, E.; Sen, B.H.; Güngör, M.A. Bond Strengths of All-Ceramics: Acid vs. Laser Etching. Oper. Dent. 2007, 32, 173-178. [CrossRef]

23. Vignesh, S.N.; Bhuminathan, M.; Santhosh, S. Comparative evaluation of the three different surface treatments-Conventional, laser and Nano technology methods in enhancing the surface characteristics of commercially pure titanium discs and their effects on cell adhesion: An in vitro study. J. Pharm. Bioallied Sci. 2015, 7, 89-91. [CrossRef]

24. Akin, H.; Tugut, F.; Topcuoglu, S.; Kirmali, O. Effects of Sandblasting and Laser Irradiation on Shear Bond Strength of Low-fusing Porcelain to Titanium. J. Adhes. Dent. 2013, 15, 55-63. [CrossRef] [PubMed]

25. Saygin, A.G.; Özdemir, A.K.; Görler, O. Influence of Various Laser Surface Modifications on SBS of Titanium and Zirconium Oxide Substructures. Cumhur. Sci. J. 2017, 38, 245. [CrossRef]

26. Dundar, B.; Guzel, K.G. An analysis of the shear strength of the bond between enamel and porcelain laminate veneers with different etching systems: Acid and Er, Cr: YSGG laser separately and combined. Lasers Med. Sci. 2010, 26, 777-782. [CrossRef]

27. Chaiyabutr, Y.; McGowan, S.; Phillips, K.M.; Kois, J.C.; Giordano, R.A. The effect of hydrofluoric acid surface treatment and bond strength of a zirconia veneering ceramic. J. Prosthet. Dent. 2008, 100, 194-202. [CrossRef]

28. Bhandari, K.S.; Moldi, A.I.; Nagral, S.; Deshpandey, S.; Kulkarni, P. Effect of sandblasting on fracture load of titanium ceramic crowns. J. Indian Prosthodont. Soc. 2015, 15, 224-228. [CrossRef] [PubMed]

29. Golebiowski, M.; Wolowiec, E.; Klimek, L. Airborne-particle abrasion parameters on the quality of titanium-ceramic bonds. J. Prosthet. Dent. 2015, 113, 453-459. [CrossRef]

30. Walczak, M. Influence of Selected Technological Procedures on the Service Life of Metal-Ceramic Systems Used in Dental Prosthetics; Habilitation Monograph; Lublin University of Technology: Lublin, Poland, 2014; p. 187.

31. Papadopoulos, T.; Tsetsekou, A.; Eliades, G. Effect of aluminum oxide sandblasting on cast commercially pure titanium surfaces. Eur. J. Prosthodont. Restor. Dent. 1999, 7, 15-21. [PubMed]

32. Kou, Z.; Yi, Q.; Zhi, X.Z. The effect of different size of aluminum oxide for sandblasting on bonding strength of porcelain to metal. Zhonghua Kou Qiang Yi Xue Za Zhi. 1994, 29, 229-231. 
33. Cai, Z.; Bunce, N.; E Nunn, M.; Okabe, T. Porcelain adherence to dental cast CP titanium: Effects of surface modifications. Biomaterials 2001, 22, 979-986. [CrossRef]

34. Akyil, M.S.; Yilmaz, A.; Karaalioğlu, O.F.; Duymuş, Z.Y.; Akyıl, M. Shear Bond Strength of Repair Composite Resin to an Acid-Etched and a Laser-Irradiated Feldspathic Ceramic Surface. Photomed. Laser Surg. 2010, 28, 539-545. [CrossRef]

35. Guilherme, N.; Wadhwani, C.; Zheng, C.; Chung, K.-H. Effect of surface treatments on titanium alloy bonding to lithium disilicate glass-ceramics. J. Prosthet. Dent. 2016, 116, 797-802. [CrossRef]

36. Antanasova, M.; Kocjan, A.; Kovač, J.; Žužek, B.; Jevnikar, P. Influence of thermo-mechanical cycling on porcelain bonding to cobalt-chromium and titanium dental alloys fabricated by casting, milling, and selective laser melting. J. Prosthodont. Res. 2018, 62, 184-194. [CrossRef] [PubMed]

37. Yilmaz, K.; Gonuldas, F.; Ozturk, C. The effect of repeated firings on the color change of dental ceramics using different glazing methods. J. Adv. Prosthodont. 2014, 6, 427-433. [CrossRef]

38. Yang, J.; Kelly, J.R.; Bailey, O.; Fischman, G. Porcelain-titanium bonding with a newly introduced, commercially available system J. Prosthet. Dent. 2016, 116, 98-101. [CrossRef] [PubMed]

39. García-Sanz, V.; Paredes-Gallardo, V.; Mendoza-Yero, O.; Leal, M.C.; Albaladejo, A.; Montiel-Company, J.M.; Bellot-Arcís, C. The effects of lasers on bond strength to ceramic materials: A systematic review and meta-analysis. PLoS ONE 2018, 13, e0190736. [CrossRef] [PubMed]

40. Papia, E.; Arnoldsson, P.; Baudinova, A.; Jimbo, R.; Von Steyern, P.V. Cast, milled and EBM-manufactured titanium, differences in porcelain shear bond strength. Dent. Mater. J. 2018, 37, 214-221. [CrossRef] [PubMed]

41. Sawada, T.; Schille, C.; Schweizer, E.; Geis-Gerstorfer, J.; Takemoto, S. Bond strength of commercial veneering porcelain to experimental cast Ti-Cr alloy. Dent. Mater. J. 2020, 39, 825-833. [CrossRef]

42. ISO. Metal Ceramic Dental Systems; ISO 9693:1999; International Organization for Standardization: Geneva, Switzerland, 2019.

43. Duceratin Kiss Directions for Use GB-DeguDent/Distributed by: Dentsply International Inc. Prosthetics Division. 2017. Available online: https:/ / www.dentsplysirona.com/content/dam/dentsply/pim/manufacturer/Prosthetics/Fixed/Ceramics/ Veneering_Porcelain/Duceram_Kiss/Ansichts-PDF_DFU_Duceram\%20Kiss_multi_2017_09.pdf (accessed on 14 October 2021).

44. Lubas, M. The impact of an innovative sandblasting medium on the titanium-dental porcelain joint. Ceram. Mater. 2019, 3, 276-285.

45. Lubas, M.; Jasinski, J.J.; Jeleń, P.; Sitarz, M. Effect of $\mathrm{ZrO}_{2}$ sol-gel coating on the Ti 99.2-Porcelain bond strength investigated with mechanical testing and Raman spectroscopy. J. Mol. Struct. 2018, 1168, 316-321. [CrossRef]

46. Chakmakchi, M.; Eliades, G.; Zinelis, S. Bonding agents of low fusing cpTi porcelains: Elemental and morphological characterization. J. Prosthodont. Res. 2009, 53, 166-171. [CrossRef]

47. Guo, L.; Shi, Y.; Guo, L.; Zhang, Q.; Tian, J.; Zhu, Y.; Guo, T. Preparation and characterization of a titanium bonding porcelain Mater. Sci. Eng. C 2012, 32, 1531-1535. [CrossRef]

48. Troia, M.G.; Henriques, G.E.; Mesquita, M.F.; Fragoso, W.S. The effect of surface modifications on titanium to enable titaniumporcelain bonding. Dent. Mater. 2008, 24, 28-33. [CrossRef]

49. Elsaka, S.E.; Swain, M. Effect of surface treatments on adhesion of low-fusing porcelain to titanium as determined by strain energy release rate. Dent. Mater. 2011, 27, 1213-1220. [CrossRef]

50. Banaszek, K.; Pietnicki, K.; Klimek, L. The influence of parameters of abrasive jet machining processing on the number of stubble elements stuck in nickel-chrome alloy surface. Mater. Eng. 2011, 32, 312-315.

51. Craig, R.; Powers, M.; Wataha, J. Dental Materials; Elsevier Urban \& Partner Editors: Wroclaw, Poland, $2000 ;$ p. 324

52. Kula, Z.; Kołodziejczyk, Ł.; Szymanowski, H. Influence of the intermediate layer on the metal-ceramics bond strength. Eng. Biomater. 2019, 152, 21-28.

53. Pacheco de Castro Henriques, B. Bond Strength Enhancement of Metal-Ceramic Dental Restorations by FGM Design. Ph.D. Thesis, Universidade do Minho, Braga, Portugal, 2012. 